\title{
Investment Bank Reputation and IPO Qualifications
}

\author{
Yubo Li \\ Division of Accounting, SHU-UTS SILC Business School, \\ Shanghai University, Jiading District, Shanghai, PR China
}

doi: 10.19044/esj.2016.v12n16p54 URL:http://dx.doi.org/10.19044/esj.2016.v12n16p54

\begin{abstract}
This study examines the influence of investment bank's reputation and political connection on the IPO qualification of Chinese firms. The results show that firms which are sponsored by prestigious investment banks are more likely to pass the regular screening process. Also, the investment bank's political connections have no significant impact on the IPO qualification. Furthermore, we compared the various investment banks' customer's characteristic. Thus, the results show that the customers of prestigious investment banks have more large-scale, are high growth companies, and are more central enterprises. This indicates that high reputation investment banks tend to choose low risk and high growth prospective IPO companies in order to avoid damage to the reputation.
\end{abstract}

Keywords: IPO qualifications, Investment bank reputation, Political connection, China

\section{Introduction}

How do we avoid the lemons firms in the capital market? China's capital market has two thresholds. One is the certification of investment bank, while the other was approved by the China Securities Regulatory Commission (CSRC). However, this commission operates under the authority of the State Council. There is a principal-agent relationship between investment banking and supervision department, which is similar to the investors. To ensure that the company recommended by the investment bank is a good company, China securities regulatory authorities introduced the sponsor system form ATM market in the UK and the Hong Kong market. Investment banks have sponsor qualification. They are responsible for recommending the listed companies. Also, they continue to monitor the company's disclosure behavior listed within two years. Thus, if any violation occurs, the sponsor must bear some responsibility. Also, the sponsor will be punished by the regulatory authorities. As a result, investment banks are 
highly motivated to carry out checks on the quality of the enterprise, in order to maintain its reputation

Whether an investment bank can choose a qualified enterprise is dependent on its ability and independence. High reputation investment banks usually have more professional research teams. They are more likely to hire high-quality auditors and to find potential problems in the enterprise. On the other hand, high reputation investment banks usually have more customers. Also, the impact of a single customer on its business is weak, and it is more likely to maintain a high level of independence. Therefore, high reputation investment banks are more likely to have a rigorous examination of the quality of the enterprise. As a result, this leads to the enhancement of the possibility of its customers through approval. In addition to strict standards to improve the audit pass rate, investment banks may also establish relationships with the government to enable its customers to receive preferential treatment of the audit institutions. Thus, this helps in improving the audit by the interest rate. Yang (2013) shows that firms whose auditor have political relationship are more likely to pass the IPO approval. Therefore, the question of this paper shows: 1) whether the investment bank's reputation can affect its customer IPO qualifications? 2) whether the investment bank's political relationship can affect its customer's IPO qualifications?

Consequently, this paper has two major contributions. First, the previous research on the reputation of investment banks mainly focused on the degree of earnings management before the listing, the first day underpricing rate, and the long-term rate of return. This paper considers whether the reputation can reduce the information asymmetry between the investment bank and the supervision department. Additionally, it also aims at improving the possibility of the customer to obtain the approval of the government. This was done from the perspective of the relationship between investment banks and government agency. Second, the previous studies on the economic consequences of political relations are mainly focused on the enterprise. Thus, there is less literature on the political relationship between financial intermediaries. Yang (2013) studied the value of the auditor's political relationship. Furthermore, this paper examines the economic consequences of the investment bank's political relationship.

\section{Related Literature}

Carter \& Manaster (1990) show that there is significant negative relationship between underwriter reputation and IPO initial returns. Therefore, high reputation underwriters can significantly reduce the information asymmetry between the issuer and investors. In addition, it also reduces the cost of the capital of issuers. Michaely \& Shaw (1994) study also 
show that the higher the underwriter reputation, the lower the first day return of its underwriting project. Thus, the long-term rate of return is higher. Carter et al. (1998) show that underwriter reputation and post IPO long-term return has a significant positive correlation. The underwriter reputation is high, and the post IPO long-run return is higher. Furthermore, they opine that the underwriter reputation and the first day return have a significant negative correlation. Therefore, the underwriter reputation is high, and the IPO underpricing rate is low.

Fernando et al. (2005) shows that issuers and the underwriters associate by mutual choice. However, large-scale and high quality issuers are more likely to choose more prestigious underwriters. Jo et al. (2007) examines the association between the choice of investment bank and earning management. Hence, the results show that there is an inverse association between underwriter quality and earning management. Underwriter quality is positively related to SEOs' post-issue performance. Agrawal \& Coorper (2010) show that the probability of restatement by an initial public offering (IPO) firm is positively related to the reputation of the underwriter. The results suggest that underwriters' concerns about revenue generation outweigh their concerns about reputation. Chang et al. (2010) show that IPO firms, with more prestigious underwriters, are likely to exhibit substantially less-aggressive earnings management. This indicates that prestigious underwriters will carefully monitor and certify financial information on IPO firms. Thus, this can be done by limiting any potential earnings manipulation to protect their reputation.

Su \& Bangassa (2011) examines the effect of underwriter reputation on IPO first day return and post IPO long-term return in China as a share market. The results show that there was no significant relationship between underwriter reputation and IPO initial return. Nevertheless, the underwriter reputations have a significant positive impact on the post IPO long-term return. By using Chinese IPO firms as a sample, Chen et al. (2013) examines the relationship between the underwriter reputation and pre-IPO earnings management behavior. They discovered that compared to state-owned holding companies, underwriter reputation have a negative significant effect on the non-state-owned company’s pre-IPO earnings management.

Consequently, by using Chinese companies as a sample, Francis et al. (2009) examines the effect of political relation on the firm's listing characteristic. The results show that political related firms have a higher PE ratio. Also, the underpricing rate is lower, while political connections can help enterprise to obtain more funds through IPO. They are also used in examining the effect of the underwriter's political relations, and to find firms whose underwriter have political connection with a higher PE ratio always. Furthermore, the first day return is always lower. Yang (2013) studied the 
effect of political relations of auditor business. Therefore, the results show that political related audit firms have higher market share, higher audit fees, and more customers through the IPO Audit Commission.

\section{Methodology}

Table 1 details our sample selection procedures for IPO application firms. We limit our sample to 2004-2015 because from the beginning of 2004, China started the implementation of the sponsor system. As a result, we have 1757 prospective IPO companies, of which 1523 companies pass the IPO screening process. On the other hand, 234 companies did not get through. The data of this paper comes from WIND.

Table 1. Sample Selection Procedures

$\begin{array}{cc}\text { Initial sample of IPO application firms over the period 2004-2015 } & \text { total } \\ \text { Exclude firms in the financial industry } & 1892 \\ \text { Exclude firms with missing data } & 28 \\ \text { Final sample } & 107 \\ \text { Pass } & 1757 \\ \text { Not pass } & 1523(86.7 \%) \\ \end{array}$

To determine whether investment bank's reputation improve the possibility of IPO approval for their clients, the following logistic models were estimated.

$$
\begin{aligned}
& \text { prob(approve }=1)_{i, t}=\alpha_{0}+\alpha_{1} \text { REPU }_{i, t}+\alpha_{2} \text { CENTR_UW }_{i, t}+\alpha_{3} \text { SIZE }_{i, t-1} \\
& +\alpha_{4} \text { OPROA }_{i, t-1}+\alpha_{5} \text { GROWTH }_{i, t-1}+\alpha_{6} \text { LEV }_{i, t-1}+\alpha_{7} \text { INTAN }_{i, t-1} \\
& +\alpha_{8} \text { CENTR }_{i, t-1}+\alpha_{9} \text { MULAPP }_{i, t}+\alpha_{10} \text { MKTRET }_{i, t}+\alpha_{11} \text { GEM }_{i, t} \\
& +\alpha_{12} \text { SMB }_{i, t}+\text { YEAR }+I N D U+\varepsilon
\end{aligned}
$$

REPU is underwriter reputation variables. If in year $\mathrm{t}-1$, investment bank's IPO business market share ranked in the top ten, then the variable is equal to 1 . Otherwise, it is equal to 0. Furthermore, if the estimated coefficient of the variable is significantly positive, this indicates that IPO application firm which is recommended by high reputation investment banks is more likely to pass the screening process.

CENTR_UW, which is an investment bank, is defined to be central government-controlled if the immediate largest shareholder of the investment bank is the Ministry of Finance or the State-owned Assets Supervision and Administration Commission (SASAC). China's financial market is highly regulated by the central government. As a result, we adopted the central government holding company as an alternative to the political relationship. If the estimated coefficient of this variable is significantly positive, this 
indicates that the investment bank's political relationship can improve the probability of obtaining the listing qualification for their clients. Table 2 is the specific definition of other control variables.

Table 2. Variable definitions

\begin{tabular}{|c|c|}
\hline $\begin{array}{c}\text { Prob } \\
\text { (approve }=1 \text { ) }\end{array}$ & $\begin{array}{c}\text { The variable is equal to } 1 \text { if the firm passes the screening process; } \\
\text { otherwise, it is equal to } 0 .\end{array}$ \\
\hline REPU_UW ${ }_{i, t}$ & $\begin{array}{l}\text { The variable is equal to } 1 \text { if investment bank's IPO business market share } \\
\text { ranked in the top ten in year t- } 1 \text {; otherwise, it is equal to } 0 \text {. }\end{array}$ \\
\hline CENTR_UW ${ }_{\mathrm{i}, \mathrm{t}}$ & $\begin{array}{l}\text { The variable is equal to } 1 \text { if the investment bank's largest shareholder is } \\
\text { the Ministry of Finance or the State-owned Assets Supervision and } \\
\text { Administration Commission (SASAC); otherwise, it is equal to 0. }\end{array}$ \\
\hline OPROA $_{\mathrm{i}, \mathrm{t}-1}$ & Annual operating income divided by the average total assets in year t-1. \\
\hline $\mathrm{LEV}_{\mathrm{i}, \mathrm{t}-1}$ & Total debts divided by total assets in year t-1. \\
\hline SIZE $_{\mathrm{i}, \mathrm{t}-1}$ & Natural logarithm of total assets in year t-1. \\
\hline GROWTH $_{\mathrm{i}, \mathrm{t}-1}$ & The annual sales growth rate in year t-1 \\
\hline INTAN $_{\mathrm{i}, \mathrm{t}-1}$ & Intangible assets divided by total assets in year t-1 \\
\hline CENTR $_{\mathrm{i}, \mathrm{t}-1}$ & $\begin{array}{c}\text { The variable is equal to } 1 \text { if the firm is controlled by the central } \\
\text { government. }\end{array}$ \\
\hline MULAPP $_{\mathrm{i}, \mathrm{t}}$ & $\begin{array}{c}\text { The variable is equal to } 1 \text { if the company has applied IPO before; } \\
\text { otherwise, it is equal to } 0 .\end{array}$ \\
\hline MKTRET $_{\mathrm{i}, \mathrm{t}}$ & $\begin{array}{c}\text { Cumulative rate of return on the Shanghai Composite Index for the year } \\
\text { before the company's Application. }\end{array}$ \\
\hline $\mathrm{GEM}_{\mathrm{i}, \mathrm{t}}$ & $\begin{array}{c}\text { The variable is equal to } 1 \text { if the company applies for listing on the GEM; } \\
\text { otherwise, it is equal to } 0 .\end{array}$ \\
\hline $\mathrm{SMB}_{\mathrm{i}, \mathrm{t}}$ & $\begin{array}{c}\text { The variable is equal to } 1 \text { if the company is listed on the SME board } \\
\text { market; otherwise, it is equal to } 0\end{array}$ \\
\hline YEAR & Year dummy variable \\
\hline INDU & Industry dummy variable \\
\hline
\end{tabular}

Table 3 reports the descriptive statistics of the variables for both firms which passed the CSRC's screening process and firms that do not pass. Thus, it can be seen that out of 1757 of the samples, $87 \%$ of the sample pass the CSRC's screening process, and 13\% of the companies did not pass. $45 \%$ of the approved company hired a high reputable investment bank as a sponsor. In the companies that do not pass the screening process, only $37 \%$ of the company hired a high-reputation investment bank. Thus, this difference is significant. There is no significant difference in the types of ultimate controlling shareholder of investment bank. The size of approved companies is significantly greater than the companies not approved. Nevertheless, the growth rate of the approved company is lower than the company that is not approved. Table 4 reports the correlation coefficients. The investment bank's reputation is positively related to the size and growth of the enterprise. Also, central government controlled companies are more likely to choose a high-reputation underwriter. 
Table 3. Descriptive statistics

\begin{tabular}{|c|c|c|c|c|c|c|}
\hline \multirow[b]{2}{*}{ Variable } & \multicolumn{2}{|c|}{ pass(1523) } & \multicolumn{2}{|c|}{ not pass(234) } & \multirow[b]{2}{*}{$\mathrm{T}$} & \multirow[b]{2}{*}{$\mathrm{Z}$} \\
\hline & mean & p50 & mean & p50 & & \\
\hline REPU_UW & 0.45 & 0.00 & 0.37 & 0.00 & $2.42^{* *}$ & $2.42^{* *}$ \\
\hline CENTR_UW & 0.22 & 0.00 & 0.20 & 0.00 & 0.91 & 0.91 \\
\hline OPROA & 0.15 & 0.13 & 0.15 & 0.13 & 0.13 & 0.21 \\
\hline SIZE & 20.28 & 20.06 & 19.97 & 19.82 & $4.01^{* * *}$ & $3.80^{* * * *}$ \\
\hline GROWTH & 1.28 & 1.21 & 1.32 & 1.25 & 1.63 & $1.93 *$ \\
\hline LEV & 0.45 & 0.45 & 0.46 & 0.45 & 0.80 & 0.86 \\
\hline INTAN & 0.05 & 0.04 & 0.05 & 0.04 & 0.31 & 0.52 \\
\hline CENTR & 0.06 & 0.00 & 0.02 & 0.00 & $2.19^{* *}$ & $2.19^{* *}$ \\
\hline MULAPP & 0.07 & 0.00 & 0.03 & 0.00 & $2.42^{* *}$ & $2.42^{* *}$ \\
\hline MKTRET & 16.68 & 7.64 & 8.82 & -3.74 & $3.21^{* * *}$ & $3.44^{* * * *}$ \\
\hline GEM & 0.34 & 0.00 & 0.32 & 0.00 & 0.57 & 0.57 \\
\hline SMB & 0.49 & 0.00 & 0.54 & 1.00 & 1.54 & 1.54 \\
\hline
\end{tabular}

\section{Regression Results}

Table 5 reports the regression results of the model (1). The estimated coefficient of REPU_UW is 0.416 , which is significant at the $1 \%$ level. However, this indicates that firms which were recommended by highreputation investment banks are more likely to pass the audit. The estimated coefficient of CENTR_UW is 0.078. Nevertheless, they are not significant. This indicates that the type of ultimate controlling shareholder of the investment bank has no significant impact on the enterprise audit pass rate.

The estimated coefficient of OPROA is 3.004. It is significant at the $10 \%$ level, and the estimated coefficient of size is 0.738 . Therefore, this shows that large and profitable enterprises are more likely to pass the audit. The estimated coefficient of MULAPP is 1.2. It is significant at the $1 \%$ level, and indicates that the re-application is more likely to pass the audit. The estimated coefficient of GEM and SMB are significantly positive. This indicates that compared to the main board market, the IPO audit pass rate is higher in GEM and in small and medium enterprises board market.

Table 6 reports the characteristics of prospective IPO companies sponsored by different reputation investment banks. Also, we divided the companies into two groups: one group is sponsored by the high reputation investment bank, while the other group is sponsored by low reputation investment bank. Then, we compared the financial performance differences between the two groups. We found that, compared to the companies sponsored by the low reputation investment banking, companies sponsored by high reputation investment are significantly higher in the scale and growth. In addition, there are more central enterprises recommended by high reputation investment banks. Therefore, considering their own interests, high reputation investment banks tend to choose low-risk and highly profitable business. Nevertheless, these companies are more likely to pass the CSRC's screening process. 


\begin{tabular}{|c|c|c|c|c|c|c|c|c|c|c|c|}
\hline & $\begin{array}{l}\text { APPR } \\
\text { OVE }\end{array}$ & $\begin{array}{c}\text { REPU_U } \\
\text { W }\end{array}$ & $\begin{array}{l}\text { CENTR_ } \\
\text { UW }\end{array}$ & OPROA & LEV & SIZE & $\begin{array}{c}\text { GROWT } \\
\text { H }\end{array}$ & $\begin{array}{c}\text { INTA } \\
\mathrm{N}\end{array}$ & $\begin{array}{l}\text { CEN } \\
\text { TR }\end{array}$ & $\begin{array}{c}\text { MU } \\
\text { LAP } \\
\text { P }\end{array}$ & $\begin{array}{l}\text { MK } \\
\text { TR } \\
\text { ET }\end{array}$ \\
\hline $\begin{array}{l}\text { APPR } \\
\text { OVE }\end{array}$ & 1 & & & & & & & & & & \\
\hline $\begin{array}{l}\text { REPU } \\
\text { _UW }\end{array}$ & $\begin{array}{c}0.058 * \\
*\end{array}$ & 1 & & & & & & & & & \\
\hline $\begin{array}{l}\text { CENT } \\
\text { R UW }\end{array}$ & 0.022 & -0.036 & 1 & & & & & & & & \\
\hline $\begin{array}{c}\text { OPRO } \\
\text { A }\end{array}$ & 0.003 & 0.039 & 0.017 & 1 & & & & & & & \\
\hline LEV & -0.019 & -0.028 & 0.038 & $\begin{array}{c}- \\
0.553^{* * *}\end{array}$ & 1 & & & & & & \\
\hline SIZE & $\begin{array}{c}0.095 * \\
* *\end{array}$ & $0.094 * * *$ & $0.178 * * *$ & $\begin{array}{c}- \\
0.399 * * *\end{array}$ & $0.473 * * *$ & 1 & & & & & \\
\hline $\begin{array}{l}\text { GRO } \\
\text { WTH }\end{array}$ & -0.039 & $0.054 * *$ & 0.021 & $0.168^{* * *}$ & -0.008 & -0.008 & 1 & & & & \\
\hline $\begin{array}{c}\text { INTA } \\
\mathrm{N}\end{array}$ & 0.007 & -0.004 & -0.021 & -0.017 & -0.036 & 0.027 & $\begin{array}{c}- \\
0.118^{* * *}\end{array}$ & 1 & & & \\
\hline $\begin{array}{c}\text { CENT } \\
\text { R }\end{array}$ & $\begin{array}{c}0.052^{*} \\
*\end{array}$ & $0.041^{*}$ & $0.153^{* * *}$ & $\begin{array}{c}- \\
0.117^{* * *}\end{array}$ & $0.112^{* * *}$ & $\begin{array}{c}0.332 * \\
* *\end{array}$ & -0.013 & -0.035 & 1 & & \\
\hline $\begin{array}{l}\text { MUL } \\
\text { APP }\end{array}$ & $\begin{array}{c}0.058^{*} \\
*\end{array}$ & 0.007 & $-0.048 * *$ & $-0.043^{*}$ & -0.028 & 0.034 & -0.036 & -0.002 & $\begin{array}{c}- \\
0.02 \\
0\end{array}$ & 1 & \\
\hline $\begin{array}{l}\text { MKTR } \\
\text { ET }\end{array}$ & $\begin{array}{c}0.076^{*} \\
* *\end{array}$ & 0.009 & 0.011 & $\begin{array}{c}- \\
0.113^{* * *}\end{array}$ & $-0.056 * *$ & $\begin{array}{c}0.113^{*} \\
* *\end{array}$ & -0.009 & $\begin{array}{c}- \\
0.063 * \\
*\end{array}$ & $\begin{array}{l}0.09 \\
3 * * *\end{array}$ & $\begin{array}{c}- \\
0.03 \\
6\end{array}$ & 1 \\
\hline
\end{tabular}

Table 4. Correlation

Table 5. Regression results

\begin{tabular}{|c|c|c|c|}
\hline & $\begin{array}{c}\text { (1) } \\
\text { Approve }\end{array}$ & $\begin{array}{c}\text { (2) } \\
\text { approve }\end{array}$ & $\begin{array}{c}\text { (3) } \\
\text { approve }\end{array}$ \\
\hline REPU_UW & $\begin{array}{c}0.504^{* * *} \\
(3.34)\end{array}$ & & $\begin{array}{c}0.416^{* * *} \\
(3.01)\end{array}$ \\
\hline CENTR_UW & & $\begin{array}{l}0.132 \\
(0.72)\end{array}$ & $\begin{array}{l}0.078 \\
(0.36)\end{array}$ \\
\hline OPROA & & & $\begin{array}{l}3.004^{*} \\
(1.75)\end{array}$ \\
\hline LEV & & & $\begin{array}{l}-1.223 \\
(-1.38)\end{array}$ \\
\hline SIZE & & & $\begin{array}{c}0.738^{* * * *} \\
(5.23)\end{array}$ \\
\hline GROWTH & & & $\begin{array}{l}-0.039 \\
(-0.13)\end{array}$ \\
\hline INTAN & & & $\begin{array}{l}0.294 \\
(0.19)\end{array}$ \\
\hline CENTR & & & $\begin{array}{l}0.598 \\
(1.10)\end{array}$ \\
\hline MULAPP & & & $\begin{array}{c}1.200^{* * * *} \\
(2.97)\end{array}$ \\
\hline MKTRET & & & $\begin{array}{l}0.003 \\
(1.26)\end{array}$ \\
\hline GEM & & & $\begin{array}{c}1.442^{* * * *} \\
(4.85)\end{array}$ \\
\hline SMB & & & $\begin{array}{c}1.024^{* * * *} \\
(4.23)\end{array}$ \\
\hline _cons & $\begin{array}{l}0.138 \\
(0.15)\end{array}$ & $\begin{array}{l}0.434 \\
(0.47)\end{array}$ & $\begin{array}{c}-14.985^{* * *} \\
(-5.08)\end{array}$ \\
\hline $\begin{array}{c}N \\
\text { pseudo } R^{2}\end{array}$ & $\begin{array}{l}1717 \\
0.062\end{array}$ & $\begin{array}{l}1717 \\
0.054\end{array}$ & $\begin{array}{l}1717 \\
0.104\end{array}$ \\
\hline
\end{tabular}


Table 6. The characteristics of prospective IPO companies

\begin{tabular}{ccccccc}
\hline & \multicolumn{2}{l}{ REPU_UW=1(774) } & \multicolumn{2}{l}{ REPU_UW=0(983) } & & \\
Variable & Mean & $\mathrm{p} 50$ & mean & $\mathrm{p} 50$ & $\mathrm{~T}$ & $\mathrm{Z}$ \\
OPROA & 0.151 & 0.136 & 0.145 & 0.131 & 1.62 & 1.59 \\
SIZE & 20.350 & 20.091 & 20.145 & 19.993 & $3.94^{* * *}$ & $3.53^{* * *}$ \\
GROWTH & 1.311 & 1.236 & 1.274 & 1.202 & $2.27^{* *}$ & $2.34^{* *}$ \\
LEV & 0.451 & 0.447 & 0.460 & 0.457 & 1.19 & 1.2 \\
INTAN & 0.051 & 0.041 & 0.052 & 0.044 & 0.17 & 0.22 \\
CENTR & 0.061 & 0.000 & 0.043 & 0.000 & $1.71^{*}$ & $1.71^{*}$ \\
\hline
\end{tabular}

\section{Conclusion}

This paper examines the influence of investment bank's reputation and political connection on their clients' IPO qualification. The results show that firms which are sponsored by prestigious investment banks are more easily approved by the government. Also, the investment bank's political connections have no significant impact on the IPO qualification. Furthermore, we compared the investment bank's customer characteristic, and find that High reputation investment bank's customers have more largescale, are high growth companies, and are more central enterprises. This indicates that high reputation investment bank tends to choose low risk and high growth prospective IPO companies in order to avoid damage to reputation.

\section{References:}

Agrawal \& Cooper (2010). Accounting Scandals in IPO Firms: Do Underwriters and VCs Help? Journal of Economics \& Management Strategy, 19, 1117-1181.

Carter \& Manaster (1990). Initial public offerings and underwriter reputation. Journal of Finance, 45, 1045-1067.

Carter et al. (1998). Underwriter reputation, initial returns and the long-run performance of IPO stocks. Journal of Finance, 53, 285-311.

Chang et al. (2010). Underwriter reputation, earning management and the long-run performance of initial public offerings. Accounting \&Finance, 50, 53-78.

Chemmanur \& Fulghier (1994). Investment bank reputation, information production and financial intermediation. Journal of Finance, 49, 57-79.

Chen et al. (2013). Underwriter reputation, issuer ownership, and pre-IPO earning management: evidence from China. Financial Manage, 42,647-677.

Fernando et al. (2006). "Wanna Dance?” How Firms and Underwriters Choose Each Other. Journal of Finance, 60, 2437-2469.

Jo et al. (2007). Underwriter choice and earnings management: evidence from seasoned equity offerings. Review of Accounting Studies, 12, 23-59. 
Su \& Bangassa (2011).The impact of underwriter reputation on initial returns and long-run performance of Chinese IPOs, Journal of international Financial Markets, Institutions\& Money, 21, 760-791

Yang (2013). Do political connections add value to audit firms? Evidence from IPO audits in China. Contemporary Accounting Research, 30, 891-921. 